\title{
Nutritional interactions with reproduction in birds
}

By P. M. Hocking, Agricultural and Food Research Council's Poultry Research Centre, Roslin, Midlothian EH25 9PS

To interact is to act reciprocally, and in the context of nutrition and reproduction in birds may be represented by the relation:

\section{Reproduction $\rightleftharpoons$ Nutrition}

Interaction from left to right, i.e. reproduction $\rightarrow$ nutrition, dominates the study of nutrition in domestic animals. Reproduction is thought of as generating a requirement for nutrients, which if not supplied results in less than optimum (usually maximum) production. In commercial systems the size and reproductive potential and therefore the nutrient requirements of birds are frequently changed by restricting growth during the rearing period. In table-egg-laying strains (layers) the change is not large but in broiler breeder hens the effect is dramatic. This is an example of nutrition $\rightarrow$ reproduction interaction and will be discussed later in this paper.

There are four major components in the reproductive life-cycle of the bird (Fig. I). Man controls the environment of domesticated birds and maintains stable population sizes by removing eggs or young birds in much the same way as predators in the wild. The main determinant of domesticated survival is the economic production of eggs for both the table egg and broiler-meat industries. $A$ simplifying model of nutrient responses for egg production, fertility, hatchability and early chick survival will be described first. Some apparent exceptions in broiler breeders fed on a limited quantity of feed to restrict growth during rearing will then be discussed.

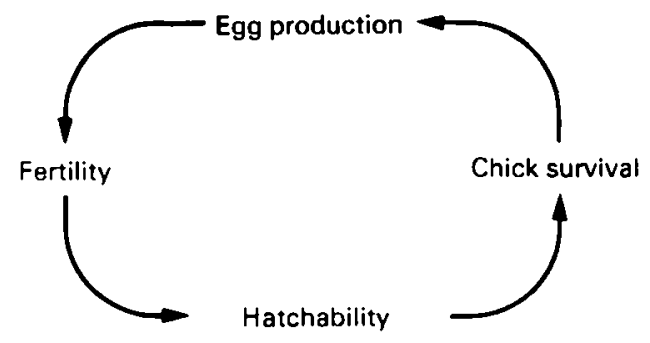

Fig. $\mathbf{I}$. The reproductive cycle in birds. 


\section{A general flock-response model}

The majority of egg production-nutrient supply relations can be summarized by the generalized flock-response model shown in Fig. 2. There is a level of nutrient supply which maintains the bird in a stable state with no production. Below this level birds will eventually die. Above this level production rises to an asymptote beyond which no further increase is observed. At some point there is a decline in production which may be caused by a limitation in another nutrient or toxicity per se.

An example from an amino acid response experiment currently in progress is presented in Table $\mathrm{x}$. Isoenergetic diets deficient in lysine but balanced as far as possible for the other amino acids were created by mixing low- and high-protein diets to give a range of calculated lysine intakes. At very high levels of dietary lysine, egg numbers, egg weight and egg mass declined. Maximum crude protein

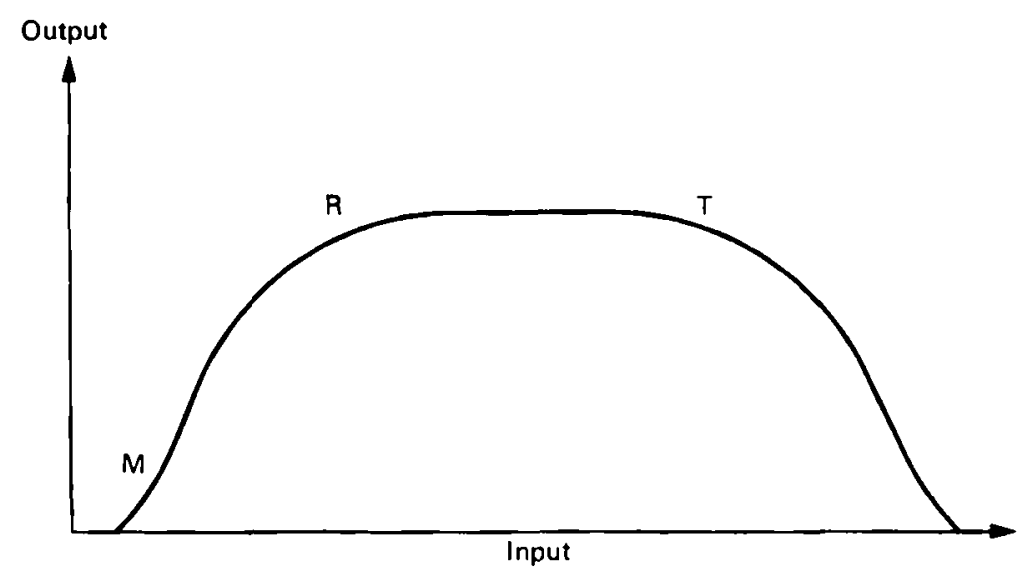

Fig. 2. A generalized flock-response model. $M$, The average maintenance level of input for a flock of birds; $R$, the requirement for optimum output; $T$, the toxic level at which output begins to decline.

Table I. Responses of broiler breeder hens to different levels of dietary lysine. (Each value is the mean of twelve birds).

\begin{tabular}{lrrrrrrrrr} 
& \multicolumn{8}{c}{ Lysine intake (mg/d) } \\
\cline { 2 - 9 } & \multicolumn{1}{c}{$3^{8}$} & 57 & 61 & 69 & 86 & 96 & 146 & 194 & 253 \\
Egg mass (g/d) & 28 & 42 & 43 & 48 & 50 & 48 & 49 & 46 & 41 \\
Egg weight (g) & 61 & 62 & 63 & 65 & 68 & 68 & 68 & 68 & 64 \\
Egg rate & 44 & 67 & 68 & 73 & 74 & 70 & 72 & 68 & 59 \\
Live-weight change (g/d) & -3 & 6 & 4 & 7 & 6 & 9 & 8 & 6 & 6 \\
Food intake (g/d) & 128 & 172 & 169 & 163 & 180 & 173 & 183 & 185 & 202
\end{tabular}

-Eggs per 100 hen days. 
(nitrogen $\times 6.25, \mathrm{CP}$ ) level was $380 \mathrm{~g} / \mathrm{kg}$ and the energy cost of amino acid absorption and catabolism may reduce the effective energy available for egg production. The changes in feed intake and live weight (Table 1 ) are consistent with the suggestion that energy is the limiting nutrient, not lysine or protein. The only direct experimental work available in support of this conclusion is that of Elwinger (1977) who supplied 0.94 of ad lib. consumption and observed decreased but parallel responses to protein and lysine.

Nutritionists have spent a considerable amount of research effort conducting empirical experiments to determine the exact points $R$ and $T$ in Fig. 2 corresponding to the requirement and toxic levels of nutrients respectively. Their recommendations are peculiar to particular experiments and in the absence of determined dose-response relations do not permit rational estimates of optimum economic levels of dietary nutrients in other circumstances. A significant advance in the analysis of response experiments occurred with the publication of an integrated individual response model for amino acids (Fisher et al. 1973). The model was based on the assumption of a simple linear relation between amino acid intake and the output characteristics for individual birds. The response for a group of birds was derived as the average of individual responses. The model accurately described the shape of the response curve (Morris \& Blackburn, 1982) and led to a rational method of predicting amino acid requirements as a function of body-weight and egg output. Estimates of the response indices (requirement for egg output and body-weight) for several amino acids in layers have been summarized by MacDonald \& Morris (1985). Mannion \& McCloud (1984) have recently extended the method to model responses to energy intake in layers. In principle there is no reason why the method should not be used to study most input-output relations provided the nutrient in question is first limiting. The many well-known relations between energy, amino acids, vitamins and minerals which affect responses to the dietary level of the nutrient are nutrient interactions, not reproduction-nutrition interactions and are not confined to birds. In effect they reduce the availability of the nutrient and obscure the true input scale.

\section{Energy and protein responses for broiler breeders}

Rates of lay in relation to body size and feed intake are low in broiler breeders, particularly during the latter half of the production cycle. Feed supply is regulated to control feed intake and improve feed:egg ratios, fertility, hatchability and chick survival, although egg production may decline if the restriction is more than $0.1-0.2$ of ad lib. intake (Proudfoot, 1979; Robblee et al. 1979; Brake \& McDaniel, r 981 ; Pearson \& Herron, 1981, 1982; Van Wambeke, r98r; McDaniel, 1983; Wilson et al. 1983). McDaniel et al. (1981) and Pearson \& Herron (1980) showed that feed control during the period from mating to peak production led to the highest egg production, hatchability and fertility. We have recently made some observations at a more fundamental level (see p. 22I) which may help to explain these apparent inconsistencies with our simple response model. 
Whitehead et al. (1985) reported reduced egg numbers and hatchability when broiler breeders were fed on a limited quantity of a diet containing $160 \mathrm{~g} \mathrm{CP} / \mathrm{kg}$ compared with a similar diet of $130 \mathrm{~g} \mathrm{CP} / \mathrm{kg}$. Recommended levels of $\mathrm{CP}$ for broiler breeders are $165 \mathrm{~g} / \mathrm{kg}$ (Agricultural Research Council, 1975) and confirm several reports that advised levels of CP for broiler breeders are not only excessive (Bornstein et al. 1979; Harms \& Wilson, 1980; Proudfoot, 1980; Pearson \& Herron, 1981, 1982) but may also lead to decreased hatchability and growth of broiler offspring (Patel \& McGinnis, 1977; Pearson \& Herron, 1981, 1982; Whitehead et al. 1985). The values in Table I are part of an experiment designed to determine input-output response parameters for amino acids in broiler breeders so that optimum feed levels can be determined in a rational fashion.

Fertility may show a decreasing trend with increasing energy intake, particularly when the higher energy allocation is made at the time of forming the breeding pens. Both sexes become larger and fatter and mating may become difficult. Duff \& Hocking (1986) have recently described extensive locomotor tissue damage among aged broiler breeder males which may lead to an unwillingness or inability to mate. Higher feed intakes may exacerbate the problem and lead to its occurrence at earlier ages. A physiological mechanism may be involved, however, since $\mathrm{McDaniel}$ et al. (198I) observed poor fertility using artificial insemination in caged broiler breeders fed on high levels of energy. Increased fatness may have made insemination more difficult, or fat may occlude the sperm storage organs or inhibit sperm transport. Alternatively a combination of two or more of these effects may conspire to reduce fertility. Fertility in young broiler breeders is low and is probably the result of immaturity in heavily restricted broiler breeder males.

\section{Age changes in response curves}

Estimates of amino acid utilization vary with age (Jennings et al. 1972; Wethli \& Morris, 1978) and strain (Pilbrow \& Morris, 1974) but this can probably be explained by differences in alternative outputs (e.g. feather growth) or rates of lay (Fisher, 1983). At low levels of egg production some birds will be consuming feed to satisfy energy requirements, protein intake will be in excess and apparent utilization poor.

Whilst the total triglyceride content and amino acid composition of the hen's egg is reasonably constant, there appears to be a direct relation between the levels of many vitamins and minerals in the plasma of the hen and chick and in the egg (Pearson, 1982). Whitehead et al. (1985) observed low levels of biotin in hen plasma, egg yolk and chick plasma in food-restricted broiler breeders at 31 weeks compared with the same birds at 41 weeks of age. It had previously been shown that biotin in hen plasma increased rapidly as birds approached sexual maturity (Whitehead, 1984). At low levels of maternal dietary biotin, hatchability and chick growth were depressed and the incidence of chick abnormalities increased.

Robel ( $198_{3}$ ) reported levels of several vitamins and minerals in whole dried eggs in two strains of turkeys at four ages. Some of his results are given in Table 2. Selenium and pantothenic acid concentrations did not change with age, biotin 
Table 2. Selected mineral and vitamin content of whole dried turkey eggs at four stages of egg production (from Robel, 1983)

Nutrient
Pyridoxine $(\mu \mathrm{g} / \mathrm{g})$
Biotin $(\mu \mathrm{g} / \mathrm{g})$
Pantothenic acid $(\mu \mathrm{g} / \mathrm{g})$
Selenium $(\mu \mathrm{g} / \mathrm{g})$
Calcium $(\mathrm{g} / \mathrm{kg})$

Nutrient

Pyridoxine $(\mu \mathrm{g} / \mathrm{g})$

Pantothenic acid $(\mu \mathrm{g} / \mathrm{g})$

Calcium ( $/ \mathrm{kg})$
Time from start of egg production (weeks)

$\begin{array}{cccc}3-5 & 5-9 & 12-16 & 19-23 \\ 41 & 41 & 10 & 7 \\ 31 & 31 & 40 & 42 \\ 4.0 & 4 \cdot 0 & 3 \cdot 7 & 3 \cdot 6 \\ 33^{8} & 349 & 349 & 3^{6} 5 \\ 110 & 137 & 94 & 93\end{array}$

NS, not significant.
Statistical

significance

$P<0.001$

$P<0.01$

NS

NS

$P<0.05$

increased, while pyridoxine and calcium declined. Robel (1983) suggested that changes in transport proteins associated with hormonal changes, reflected in the decline in egg production with age, may be responsible for these differences. The decrease in $\mathrm{Ca}$ content of whole dried egg (Table 2 ) is probably associated with changes in egg-shell thickness since there is very little $\mathrm{Ca}$ in the non-shell components of the egg. Egg-shell thickness declines with age and is a serious cause of economic loss in aged layers and of poor hatchability in broiler breeders (McDaniel et al. 1979). In young birds egg-shell porosity is low (Tullet \& Smith, 1983) and hatchability, chick performance and survival are poor (Smith \& Bohren, 1975). Fat metabolism in embryos from young hens is altered (Noble et al. 1986) and this may be related to low shell porosity which van Middelkoop (1972) has shown is a cause of poor hatchability.

\section{Feed restriction during rearing}

The consequences of feed restriction during the rearing period include a reduction in body-weight and fatness, and increased rates of lay and delayed sexual maturity, leading to higher egg weight. Fertility and hatchability are improved while increased mortality during the rearing period is offset by reduced mortality during lay (Lee et al. 1971; Pearson \& Shannon, 1979; Classen, 1983). The effect on rate of lay is permanent, continuing after force moulting into later years in layers (Fuller \& Dunahoo, r 962; Hollands \& Gowe, 1965). Hollands et al. (1965) measured the weights of the thyroid, adrenal, pituitary, spleen, liver, heart, gizzard and abdominal fat in layers raised on a restricted or ad lib. dietary regimen. At the end of the laying period only the weight of the pancreas was larger in the feed-restricted birds. Larger oviducts and more yellow ovarian follicles $(5 \cdot 5 v \cdot 5 \cdot 2)$ in restricted compared with ad lib.-fed broiler breeders were observed by Watson (1975). The size of the oviduct is directly proportional to the number of developing yellow follicles (P. M. Hocking, unpublished results) and the differences are not large enough to account for the observed differences in egg production in broiler breeders reared on restricted and ad lib. diets. 
In layers at peak production there are typically six or seven developing yellow follicles greater than $8 \mathrm{~mm}$ diameter which grow to ovulate and form successive egg yolks. There are a large number (about sixty) of small white follicles, $\mathrm{I}-8 \mathrm{~mm}$ diameter, whose normal fate is to become atretic (Gilbert et al. 1983). We have recently compared the reproductive systems of dwarf broiler breeders restricted to a live weight of $2.0 \mathrm{~kg}$ at point of lay and $a d$ lib.-fed dwarfs which weighed $3.9 \mathrm{~kg}$. The feed-restricted birds were allowed ad lib. consumption after their first egg was laid. The number of yellow follicles and egg production per 100 hen days are presented in Table 3. The feed-restricted dwarfs had fewer yellow follicles $(P<0.01)$ at first egg and at 30 weeks. The ad lib.-fed dwarfs had too many follicles giving rise to multiple ovulation and unsatisfactory egg production (Table 3). Internal ovulation, i.e. ova which fail to enter the oviduct, was frequently observed in ad lib.-fed dwarfs. If two or more yolks traverse the oviduct on a single day, one of several equally undesirable consequences follow. A multiple-yolked egg will be produced if the yolks are ovulated close together. If shell deposition has started and another yolk enters the shell gland the result may be two soft-shelled or partly shelled eggs or one or more membranous eggs. The frequency of such eggs recorded between 23 and 27 weeks of age were 0.05 and 0.22 for the feed-restricted and ad lib.-fed dwarfs respectively. The latter also had more atresia among the yellow follicles which was rare in feed-restricted broilers. Jaap \& Muir (1968) and van Middelkoop (1971) obtained similar egg records during early lay in ad lib.-fed broilers but the ovary was not examined. Johnson et al. $(1985 b)$ showed that more defective shells were produced initially in ad lib.-fed compared with feed-restricted layers. Feed restriction probably has the same effect, as in broiler breeders, of limiting the number of multiple ovulations that occur in the first 7-14 d of production in some strains of modern layers. Since the incidence may differ among strains and decline with age a variable effect of feed restriction on egg production would be expected and may explain differences among experiments on feed-restricted rearing in layers.

Table 3. Number of normal yellow follicles and egg production of dwarf broiler breeders fed ad lib. or feed-restricted to point of lay

\begin{tabular}{|c|c|c|c|c|c|c|c|c|c|c|c|c|}
\hline \multirow[b]{2}{*}{ Rearing } & \multicolumn{3}{|c|}{ First egg } & \multicolumn{3}{|c|}{30 weeks } & \multicolumn{3}{|c|}{45 weeks } & \multicolumn{3}{|c|}{60 weeks } \\
\hline & $n$ & Mean & Range & $n$ & Mean & Range & $n$ & Mean & Range & $n$ & Mean & Range \\
\hline Ad lib. & & & & & & & & & & & & \\
\hline $\begin{array}{l}\text { Follicles } \\
\text { Egg rate }\end{array}$ & 6 & $\begin{array}{l}9 \cdot 0 \\
49\end{array}$ & $\begin{array}{l}7-10 \\
8-88\end{array}$ & 8 & $\begin{array}{c}7 \cdot 3 \\
50\end{array}$ & $\begin{array}{c}5-9 \\
14-76\end{array}$ & 8 & $4^{46}$ & $\begin{array}{l}2-6 \\
5-81\end{array}$ & 14 & $3^{30}$ & $\begin{array}{l}0-11 \\
0-62\end{array}$ \\
\hline Restricted & & & & & & & & & & & & \\
\hline $\begin{array}{l}\text { Follicles } \\
\text { Egg rate }\end{array}$ & 8 & $\begin{array}{l}6.8 \\
77\end{array}$ & $\begin{array}{c}5-8 \\
5^{8-100}\end{array}$ & 8 & $\begin{array}{r}5 \cdot 6 \\
79\end{array}$ & $\begin{array}{c}5-7 \\
87-95\end{array}$ & 8 & $\begin{array}{l}4 \cdot 0 \\
50^{\circ}\end{array}$ & $\begin{array}{l}0-6 \\
0-76\end{array}$ & 8 & $\begin{array}{l}4.0 \\
18\end{array}$ & $\begin{array}{l}0-7 \\
0-48\end{array}$ \\
\hline
\end{tabular}

\footnotetext{
"Egg production between 23 and 27 weeks of age for twenty-six birds for first egg; at $3^{\circ}, 45$ and 60 weeks egg production is for 3 weeks before the examination of ovaries.

tEggs per 100 hen $\mathrm{d}$.
} 
The production of excessive numbers of yellow follicles appears to be a concomitant of selection for size (Nestor \& Bacon, 1972; Abplanalp et al. 1977, 1984). Our findings show that there were more white follicles in the ad lib.-fed birds and that the excessive production of yellow follicles was not caused by reduced atresia among the white follicles (Table 4 ). There was a positive association between live weight and the number of white and yellow follicles. Birds which ate more had fewer atretic follicles but abdominal fat was not related to the number of white or yellow follicles. Other workers have been unable to demonstrate a relation between fatness and rate of lay (Chaney \& Fuller, 1975; Johnson et al. $1985 a)$ and Hocking et al. (1985) failed to find differences in carcass fatness among several strains of layers and broiler breeders at the end of lay. It would appear that feed restriction during rearing does not improve productivity through the control of fatness. Whether the effect of live-weight control is through a fundamental change in the hypothalamic-pituitary-gonadal axis is not known. It has been known for many years that dietary restriction during growth improves reproductive life-span (see Gowe et al. 1960) and there is some evidence in rats that the hypothalamus is affected if the restriction is before weaning (Glass \& Swerdloff, 1980). Chi (1985) reported lower production in layers fed on a low-protein diet before 6 weeks of age. Low-protein diets given after 6 weeks had no effect, as has been shown by others (Blair et al. 1970; Leeson \& Summers, 1982).

\section{Conclusions}

The practical application of these results is that feed control should be applied to point of lay. Any excessive energy before lay will tend to induce multiple ovulations with attendant consequences for egg-shell quality and usable egg production. There is an inherent difficulty in this because of the range in age at sexual maturity. Delaying the onset of maturity by feed restriction or light may improve the synchronization of the onset of lay and energy supply in a flock of birds. Birds which are laying internally are able to recycle nutrients but those laying eggs which are lost through inadequate shell formation will appear to be very inefficient. Their requirements will be high since they incur a high rate of loss of nutrients affecting input-output relations.

Table 4. Number of normal small white follicles $1-8 \mathrm{~mm}$ in diameter and the proportion atretic at four ages in dwarf broiler breeders fed ad lib. or restricted to point of lay

\begin{tabular}{|c|c|c|c|c|c|c|c|c|c|c|c|c|}
\hline \multirow[b]{2}{*}{ Rearing } & \multicolumn{3}{|c|}{ First egg } & \multicolumn{3}{|c|}{30 weeks } & \multicolumn{3}{|c|}{45 weeks } & \multicolumn{3}{|c|}{60 weeks } \\
\hline & $n$ & Mean & Atretic & $n$ & Mean & $\overrightarrow{\text { Atretic }}$ & $n$ & Mean & Atretic & $n$ & Mean & Atretic \\
\hline $\begin{array}{l}\text { Ad lib. } \\
\text { Restricted }\end{array}$ & $\begin{array}{l}6 \\
8\end{array}$ & $\begin{array}{l}52 \\
36\end{array}$ & $\begin{array}{l}0.39 \\
0.31\end{array}$ & $\begin{array}{l}8 \\
8\end{array}$ & $\begin{array}{l}66 \\
51\end{array}$ & $\begin{array}{l}0.47 \\
0.41\end{array}$ & $\begin{array}{l}8 \\
8\end{array}$ & $\begin{array}{l}5^{8} \\
35\end{array}$ & $\begin{array}{l}0.50 \\
0.51\end{array}$ & $\begin{array}{r}14 \\
8\end{array}$ & $\begin{array}{l}50 \\
51\end{array}$ & $\begin{array}{l}0.46 \\
0.48\end{array}$ \\
\hline
\end{tabular}


Low hatchability in broiler breeders reared on an ad lib. diet is probably due to poor shell quality caused by multiple ovulation. There may be age-related hormonal changes in the bird which affect shell quality and the nutrient status of the egg and chick which in turn affect hatchability and chick survival. Variation in fertility is probably related to physical changes with age.

In general the simple flock response model of Fig. 2 suffices but an understanding of the major nutrition $\rightarrow$ reproduction interactions induced by restricted feeding during rearing would greatly extend our basic knowledge of the control of egg production in birds. The ovarian responses to increases in energy or amino acid supply are not known, nor are the underlying hormonal interactions. The same applies to minerals and vitamins with one notable exception. Egg production shows a typical generalized model response to $\mathrm{Ca}$ intake (Gilbert $e t$ al. $1981)$ and Waddington et al. (1985) have shown that this is caused by atresia among the rapidly growing yellow follicles. At the current time we can only speculate as to how the other nutrients affect the ovary. Increasing knowledge in this area may permit more efficient modelling and prediction of nutrient responses and reduce our dependency on empirical experimentation.

I am grateful to my colleagues Drs C. Fisher and A. B. Gilbert for allowing me to quote from unpublished collaborative work.

\section{REFERENCES}

Abplanalp, H., Lowry, D. C. \& van Middelkoop, J. H. (1977). British Poultry Science 18, 525-595.

Abplanalp, H., Tal, C. \& Napolitano, D. (1984). British Poultry Science 25, 343-347.

Agricultural Research Council (1975). The Nutrient Requirements of Farm Livestock, no. I Poultry. Slough: Commonwealth Agricultural Bureaux.

Blair, R., Bolton, W. \& Morley-Jones, R. (1970). British Poultry Science 1 I, 249-258.

Bornstein, S., Hurwitz, S. \& Levy, Y. (1979). Poultry Science 58, 104-1 16.

Brake, J. \& McDaniel, R. R. (1981). Poultry Science 60, 313-316.

Chaney, L. W. \& Fuller, H. L. (1975). Poultry Science 54, 200-207.

Chi, M. S. (1985). British Poultry Science 26, 433-440.

Classen, H. I. (1983). Proceedings of the Fourth Western Nutrition Conference. Saskatoon: University of Saskatchewan.

Duff, R. S. I. \& Hocking, P. M. (1986). Research in Veterinary Science 4I, 340-348.

Elwinger, K. (1977). In First European Symposium on Poultry Nutrition, pp. 43-53 [L. Y. Sorensen, editor]. Copenhagen: World's Poultry Science Association.

Fisher, C. (1983). In Fourth International Symposium on Protein Metabolism and Nutrition, pp. 385-404 [edited by Institut National de la Recherche Agronomique]. Clermont-Ferrand: INRA.

Fisher, C., Morris, T. R. \& Jennings, R. C. (1973). British Poultry Science 14, 469-484.

Fuller, H. L. \& Dunahoo, W. S. (1962). Poultry Science 41, I 306-1314.

Gilbert, A. B., Peddie, J., Mitchell, G. G. \& Teague, P. W. (1981). British Poultry Science 22, 537-548.

Gilbert, A. B., Perry, M. M., Waddington, D. \& Hardie, M. A. (1983). Fournal of Reproduction and Fertility 69, 221-227.

Glass, A. R. \& Swerdloff, R. S. (1980). Federation Proceedings 39, 2360-2364.

Gowe, R. S., Johnson, A. S., Crawford, R. D., Downs, J. H., Hill, A. T., Mountain, W. F., Pelletier, J. R. \& Strain, J. H. (1960). British Poultry Science 1, 37-56. 
Harms, R. H. \& Wilson, H. R. (1980). Poultry Science 59, 470-472.

Hocking, P. M., Gavora, J. S., Chambers, J. R. \& Fortin, A. (1985). Poultry Science 64, 6-28.

Hollands, K. G. \& Gowe, R. S. (1965). British Poultry Science 6, 287-295.

Hollands, K. G., Gowe, R. S. \& Morse, P. M. (1965). British Poultry Science 6, 297-310.

Jaap, R. G. \& Muir, F. V. (1968). Poultry Science 47, 417-423.

Jennings, R. C., Fisher, C. \& Morris, T. R. (1972). British Poultry Science 13, 279-281.

Johnson, R. J., Coice, A., Farrell, D. J. \& Cumming, R. D. (1985a). British Poultry Science 26, $369-387$.

Johnson, R. J., Cumming, R. B. \& Farrell, D. J. (1985b). British Poultry Science 26, 335-348.

Lee, P. J. W., Guliver, A. L. \& Morris, T. R. (1971). British Poultry Science 12, 413-437.

Leeson, S. \& Summers, J. D. (1982). Poultry Science 61, 1684-1691.

McDaniel, G. R. (1983). Poultry Science 62, 1949-1953.

McDaniel, G. R., Brake, J. \& Bushing, R. D. (I98I). Poultry Science 60, 307-312.

McDaniel, G. R., Roland, D. A. \& Coleman, M. A. (1 979). Poultry Science 58, 10-13.

MacDonald, M. W. \& Morris, T. R. (1985). British Poultry Science 26, 253-264.

Mannion, P. F. \& McCloud, P. I. (1984). British Poultry Science 25, 53-64.

Morris, T. R. \& Blackburn, H. A. (1982). British Poultry Science 23, 405-424.

Nestor, K. E. \& Bacon, W. (1972). Poultry Science 51, $1361-1365$.

Noble, R. C., Lonsdale, F., Conner, K. \& Brown, D. (1986). Poultry Science 65, 409-416.

Patel, M. B. \& McGinnis, J. (1977). Poultry Science 56, 45-53.

Pearson, R. A. (1982). In Recent Advances in Animal Nutrition-1982, pp. 141-156 [W. Haresign, editor]. London: Butterworth.

Pearson, R. A. \& Herron, K. M. (1980). British Poultry Science 21, 171-181.

Pearson, R. A. \& Herron, K. M. (1981). British Poultry Science 22, 227-229.

Pearson, R. A. \& Herron, K. M. (1982). British Poultry Science 23, 145-159.

Pearson, R. A. \& Shannon, D. W. F. (1979). In Food Regulation in Poultry, pp. 365-390 [K. N. Boorman and B. M. Freeman, editors]. Edinburgh: British Poultry Science Ltd.

Pilbrow, P. J. \& Morris, T. R. (1974). British Poultry Science 15, 4 I-73.

Proudfoot, F. G. (1979). Canadian Fournal of Animal Science 59, 749-759.

Proudfoot, F. G. (1980). Poultry Science 59, $1258-1267$.

Robblee, A. R., Clandin, D. R., Darling, K. \& Milne, G. R. (1979). Canadian Journal of Animal Science 59, 539-544.

Robel, E. J. (1983). Poultry Science 62, 1751-1 756.

Smith, K. P. \& Bohren, B. B. (1975). Poultry Science 54, 959-963.

Tullet, S. G. \& Smith, S. (1983). British Poultry Science 24, 501-509.

van Middelkoop, J. H. (1971). Archiv für Geflügelkunde 35, 122-127.

van Middelkoop, J. H. (1972). Archiv für Geflügelkunde 36, 63-70.

Van Wambeke, F. (1981). In Third European Symposium on Poultry Nutrition, pp. 25-30 [D. W. F. Shannon and I. E. Wallace, editors]. Edinburgh: World's Poultry Science Association.

Waddington, D., Perry, M. M., Gilbert, A. B. \& Hardie, M. A. (1985). Foumal of Reproduction and Fertility 74, 399-405.

Watson, N. A. (1975). British Poultry Science 16, 259-262.

Wethli, E. \& Morris, T. R. (1978). British Poultry Science 19, 559-565.

Whitehead, C. C. (1984). British Poultry Science 25, 287-292.

Whitehead, C. C., Pearson, R. A. \& Herron, K. M. (1985). British Poultry Science 26, 73-82.

Wilson, H. R., Ingram, D. R. \& Harms, R. H. (1983). Poultry Science 62, I $133^{-1} 14$ I. 